\title{
PENERAPAN ANALYTICAL HIERARCHY PROCESS (AHP) SEBAGAI MODEL PENUNJANG KEPUTUSAN PENERIMAAN MAHASISWA PROGRAM STUDI GROUND HANDLING AIRLINES PADA UNIVERSITAS MUHAMMADIYAH TANGERANG
}

\author{
Sandro Alfeno ${ }^{1}$ \\ Ferry Sudarto ${ }^{2}$ \\ Ihsan Maulana ${ }^{3}$ \\ Dosen STMIK Raharja ${ }^{1}$ \\ Dosen STMIK Raharja Tangerang ${ }^{2}$ \\ Teknik Informatika STMIK AMIKOM Yogyakarta \\ Jl. Jendral Sudirman No. 40, Modern Cikokol-Tangerang \\ e-mail: sandroalfeno@yahoo.com',ferry.sudarto@raharja.info ${ }^{2}$,iisandesign@gmail.com ${ }^{3}$
}

\begin{abstract}
ABSTRAK
Sistem Penunjang Keputusan atau dikenal dengan SPK merupakan bagian dari sistem informasi yang berbasis komputer. Dalam permasalahan yang dihadapi oleh Pendidikan dan Pelatihan program studi Ground Handling Airlines di Universitas Muhammadiyah Tangerang tepatnya pada Fakultas Pariwisata dan Industri Kreatif diantaranya adalah dalam proses penerimaan mahasiswa barunya setiap tahunnya. Metode yang dipakai dalam penelitian ini adalah metode Analytical Hierarchy Process (AHP) dalam proses pembobotan penilaian yang digunakan. Empat kriteria dasar yang digunakan yaitu nilai hasil ujian nasional, nilai wawancara yang mencakup dari penilaian fisik(Wajah, Tubuh, Postur, Kebersihan), kemampuan berkomunikasi (Bahasa Inggis, Bahasa Indonesia, Percaya Diri), Orientasi Layanan (Inisiatif, keramahan, teamwork, tanggungjawab, kemandirian), wawasan (Penerbangan, Garuda, Geography, Mata Uang, Time Diffrencee), serta presentasi dan organisasi dan prestasi akademik atau non akademik. Aplikasi sistem penunjang keputusan penerimaan mahasiswa baru ini dibuat dengan bahasa pemrograman berbasis web PHP dan MySQL sebagai database. Sistem yang dibangun ini mampu memberikan rekomendasi keputusan penerimaan mahasiswa berdasarkan bobot penilaian tertinggi. Dengan sistem ini diharapkan dapat memberikan solusi rekomendasi penerimaan mahasiswa secara cepat dengan terintergrasi oleh komputer tanpa memerlukan waktu yang tidak sedikit.
\end{abstract}

Kata kunci: SPK, Ground Handling Airlines, metode AHP.

\begin{abstract}
Decision Support System, known as DSS is part of the computer-based information systems. In the problems faced by the education and training courses Airlines Ground Handling at the Muhammadiyah University of Tangerang precisely at the Faculty of Tourism and Creative Industries of which is in the process of acceptance of new students each year. The method used in this study is Analytical Hierarchy Process (AHP) in the process of assessment weighting used. The four basic criteria used is the value of the results of the national exams, the value of interviews spanning the physical assessment (face, body, posture, Hygiene), communication skills (English Britain, Indonesian, Confidence), Orientation Service (Initiative, friendliness, teamwork, responsibility, self-reliance), insight (Flight, Garuda, Geography, Currency, Time Diffrencee), as well as presentation and organizational and academic or non-academic achievement. Decision support system application admission is made by the web-based programming
\end{abstract}


language PHP and MYSQL as a database. This system is able to provide recommendations admissions decisions based on the weight of the highest ratings. With this system is expected to provide a solution quickly admissions recommendation with integrated by computer without requiring substantial time.

Keywords: DSS, Ground Handling Airlines, AHP.

\section{PENDAHULUAN}

Sistem Penunjang Keputusan atau dikenal dengan SPK merupakan bagian dari sistem informasi yang berbasis komputer. Dalam permasalahan yang dihadapi oleh Pendidikan dan Pelatihan program studi Ground Handling Airlines di Universitas Muhammadiyah Tangerang tepatnya pada Fakultas Pariwisata dan Industri Kreatif diantaranya adalah dalam proses penerimaan mahasiswa barunya setiap tahunnya.

Dalam prosesnya, panitia menyeleksi data calon mahasiswa satu persatu pada fomulir yang telah diserahkan oleh calon mahasiswa, kemudian berdasarkan penilaian yang telah dilakukan oleh 4 dewan penguji yang kepada para calon mahasiswa, hasil yang di dapat berupa data akan disalin ulang kedalam buku besar sebagai rekap laporan penilaian calon mahasiswa. Dirasa kurang optimal serta memerlukan waktu yang cukup lama baik dalam menyusun laporan, memutuskan calon mahasiswa baru yang akan diterima setiap prosesnya. Padahal idealnya penyeleksian calon mahasiswa tersebut harus ditentukan secepat mungkin untuk mendukung mahasiswa yang lain.

Dalam menentukan kriteria apakah calon mahasiswa tersebut dinyatakan lulus atau tidaknya maka diperlukan adanya model pengambilan keputusan yang dikenal dengan Sistem Penunjang Keputusan (SPK), sehingga dapat membantu panitia penerimaan mahasiswa baru dalam mendata dan menentukan kategori dalam penerimaan mahasiswa baru sesuai dengan kriteria.

\section{PERMASALAHAN}

\section{Rumusan Masalah}

Dari uraian latar belakang di atas maka perumusan masalah dalam sistem tersebut dapat dirumuskan sebagai berikut:

a. Bagaimanakah proses penerimaan mahasiswa baru pada program studi ground handling airlines di universitas muhammadiyah tangerang yang telah berjalan saat ini?

b. Kendala apasaja yang dihadapi dalam proses penerimaan mahasiswa baru pada program studi tersebut?

c. Bagaimana merancang dan membuat sebuah sistem penunjang keputusan dalam penerimaan mahasiswa baru dengan menerapkan sebuah metode analisis hirarki proses (AHP) sebagai suatu model dalam pengambilan keputusan?

\section{Ruang Lingkup}

a. Sistem ini hanya untuk menyeleksi calon siswa baru berdasarkan kriteria-kriteria yang telah ditentukan.

b. Metode pengambilan data diproleh dari data pendaftar dan dilihat dari nilai calon mahasiswa.

c. Kriteria yang dipertimbangkan dalam penyeleksian calon siswa baru ini adalah : 
1. Nilai hasil ujuan nasional (SKHU)

2. Nilai Wawancara berdasarkan dari :

a. Penampilan Fisik (Wajah, Tubuh, Postur, Kebersihan)

b. Kemampuan berkomunikasi (Bahasa Inggris, Bahasa Indonesia, Percaya Diri)

c. Orientasi Layanan (Inisiatif, Keramahan, Teamwork, Tanggungjawab, Kemandirian)

d. Wawasan (Penerbangan, Garuda, Geography, Mata Uang, Time Difference)

e. Presentasi \& Organisasi (Sosial, Organisasi, Olahraga, Musik, Science)

3. Tinggi dan Berat badan ideal

d. Database menggunakan Mysql dan sistem pembangun menggunakan bahasa pemrograman PHP Framework.

e. Sistem ini dianalisis dan dirancang menggunakan metode Unified Modeling Language (UML) serta dikembangkan dengan suatu metode Prototyping dan akan diuji dengan menggunakan metode Black Box Testing

\section{Tujuan dan Manfaat}

\section{Tujuan}

a. Mengetahui sistem penerimaan mahasiswa baru pada program studi ground handling airlines

b. Mengetahui sebuah kendala yang dihadapi dalam proses penerimaan mahasiswa baru

c. Membangun sebuah sistem informasi penerimaan mahasiswa baru dengan memanfaatkan suatu metode Analisis Hirarki Proses (AHP)

\section{Manfaat}

a. Mendapatkan cara untuk proses dalam penerimaaan mahasiswa baru yang dilakukan oleh panitia penerimaan mahasiswa baru pada program studi ground handling airlines

b. Mendapatkan suatu model pemecahan masalah-masalah yang timbul ketika dalam proses penerimaan mahasiswa baru

c. Mempermudah serta membantu panitia penerimaan mahasiswa baru dalam meningkatkan kecepatan serta keefektifan dalam mengambil keputusan pada proses seleksi di program studi ground handling airlines

\section{TINJAUAN PUSTAKA}

\section{Definisi Sistem}

Suatu sistem dapat terdiri dari beberapa subsistem atau sistem - sistem bagian.komponen atau subsistem - subsisten dalam suatu sistem tidak dapat berdiri sendiri, melainkan saling berinteraksi dan saling berhubungan membentuk kesatuan sehingga tujuan atau sasaran sistem tersebut dapat tercapai. Ada beberapa pendapat yang menjelaskan definisi sistem, yaitu [1] :

1. Menurut Ludwig von bartalanfy, Sistem merupakan seperangkat unsur yang saling terikat dalam suatu antar realasi diantara unsur - unsur tersebut dengan lingkungan.

2. Menurut Anatol Raporot, Sistem adalah suatu kumpulan kesatuan dan perangkat hubung satu sama lain.

3. Menurut L. Ackof, Sistem adalah setiap kesatuan secara konseptual atau fisik yang terdiri dari bagian - bagian dalam keadaan saling tergantung satu sama lainnya. 
Berdasarkan beberapa pendapat yang dikemukakan diatas dapat ditarik kesimpulan bahwa sistem adalah kumpulan bagian - bagian dari tujuan.

\section{Sistem Pendukung Keputusan \\ Definisi Sistem Pendukung Keputusan}

Sistem Pendukung Keputusan (SPK) merupakan aplikasi interaktif berbasis komputer yang mengkombinasikan data dan model matematis untuk membantu proses pengambilan keputusan dalam menangani suatu masalah. ada tiga aspek utama dalam SPK yaitu : [4]

1. Data, data yang digunakan dalam SPK adalah data yang diambil dari data warehouse pada organisasi yang telah dikategorikan berdasarkan kebutuhan.

2. Model matematis, merupakan bagian untuk menganalisis data dan berfungsi untuk merubah data menjadi informasi dan knowledge yang berguna untuk pengambilan keputusan.

3. Antarmuka pengguna (user interface). Aspek ini merupakan aspek yang secara langsung dilihat dan berinteraksi dengan end user atau dalam hal ini pemegang keputusan. Data yang ditampilkan harus memberikan informasi yang valid, reliable dan dapat mendukung untuk pengambilan keputusan. (Vercellis, 2009: 36)

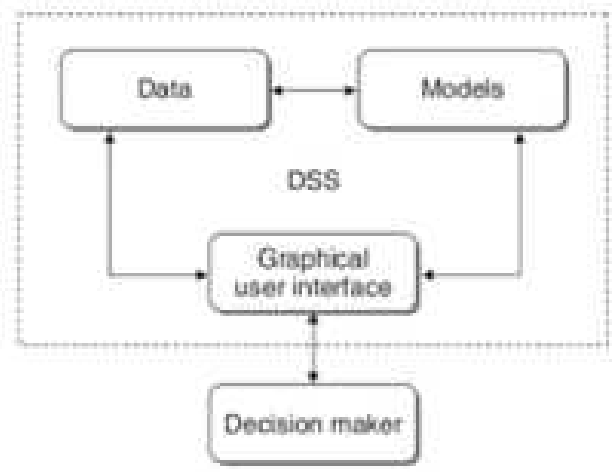

Gambar 1. Aspek Utama SPK

\section{Jenis Sistem Pendukung Keputusan (SPK)}

Menurut Steven, L Alter, SPK dapat dipilah sejalan dengan tingkat dukungannya terhadap pemecahan masalah. Ada 6 jenis Sistem Pendukung Keputusan yaitu:

1. Retrieve information element (memanggil eleman informasi).

2. Analyze entries files (menganalisa semua file).

3. Prepare reports form multiple files (laporan beberapa file).

4. Estimate decisions consequences (meramalkan akibat dari keputusan).

5. Propose decision (menawarkan keputusan).

6. Make decisions (membuat keputusan).

\section{Karakteristik Sistem Pendukung Keputusan}

Berikut ini beberapa di antaranya karakteristik dari sistem pendukung keputusan menurut Bonczek, dkk., dalam buku konsep data mining vs sistem pendukung keputusan[5]:

a. Mendukung proses pengambilan keputusan suatu organisasi atau perusahaan.

b. Adanya interface manusia/mesin dimana manusia (user) tetap memegang kontrol proses pengambilan keputusan. 
c. Mendukung pengambilan keputusan untuk membahas masalah terstruktur, semi terstruktur serta mendukung beberapa keputusan yang saling berinteraksi

d. Memiliki subsistem yang terintegrasi sedemikian rupa sehingga dapat berfungsi sebagai kesatuan sistem.

e. Memiliki dua komponen utama yaitu data dan model.

\section{Fase-Fase Proses Pengambilan Keputusan}

Ada tiga (3) fase proses pengambilan keputusan menurut Simon dalam (Hilyah Magdalena, 2012)[6], yaitu:

1. Intelligence : pengumpulan informasi untuk mengindetifikasikan permasalahan.

2. Design : tahap perancangan solusi dalam bentuk alternatif pemecahan masalah.

3. Choice : melakukan proses pemilihan diantara berbagai alternatif tindakan yang mungkin dijalankan

\section{Konsep Model Analytical Hierarchy Process \\ Definisi Analytical Hierarchy Process (AHP)}

AHP merupakan suatu model pendukung keputusan yang dikembangkan oleh Thomas L. Saaty. Model pendukung keputusan ini akan menguraikan masalah multi faktor atau multi kriteria yang kompleks menjadi suatu hirarki, menurut Saaty, hirarki didefinisikan sebagai suatu representasi dari sebuah permasalahan yang kompleks dalam suatu struktur multi level di mana level pertama adalah tujuan, yang diikuti level faktor, kriteria, sub kriteria, dan seterusnya ke bawah hingga level terakhir dari alternatif. [7]

Dengan hirarki, suatu masalah yang kompleks dapat diuraikan ke dalam kelompokkelompoknya yang kemudian diatur menjadi suatu bentuk hirarki sehingga permasalahan akan tampak lebih terstruktur dan sistematis.

AHP sering digunakan sebagai metode pemecahan masalah dibanding dengan metode yang lain karena alasan-alasan sebagai berikut:

1. Struktur yang berhirarki, sebagai konsekuesi dari kriteria yang dipilih, sampai pada subkriteria yang paling dalam.

2. Memperhitungkan validitas sampai dengan batas toleransi inkonsistensi berbagai kriteria dan alternatif yang dipilih oleh pengambil keputusan.

3. Memperhitungkan daya tahan output analisis sensitivitas pengambilan keputusan.

\section{Prinsip Analytical Hierarchy Process (AHP)}

Ada beberapa prinsip yang harus dipahami dalam menyelesaikan persoalan dengan AHP, diantaranya adalah: decomposition, comparative judgement, synthesis of priority dan logical consistency[8].

\section{Decomposition}

Setelah persoalan didefinisikan, maka perlu dilakukan decomposition yaitu memecah persoalan yang utuh menjadi unsur-unsurnya. Jika ingin mendapatkan hasil yang akurat, pemecahan juga dilakukan terhadap unsur-unsurnya sampai tidak mungkin dilakukan pemecahan lebih lanjut, sehingga didapatkan beberapa tingkatan dari persoalan tadi. Karena alasan ini, maka proses analisis ini dinamakan hirarki (hierarchy). Ada dua jenis hirarki yaitu lengkap dan tak lengkap.Dalam hirarki lengkap, semua elemen pada suatu 
tingkat memiliki semua elemen yang ada pada tingkat berikutnya. Jika tidak, dinamakan hirarki tak lengkap.

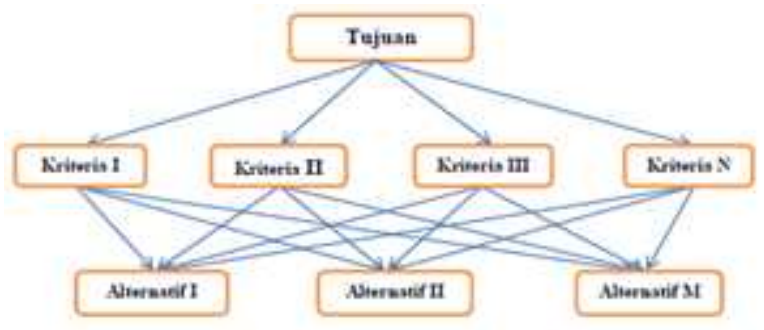

Gambar 2. Model Struktur Hirarki

2. Comparative Judgement

Prinsip ini berarti membuat penilaian tentang kepentingan relatif dua elemen pada suatu tingkat tertentu dalam kaitannya dengan tingkat di atasnya. Penilaian ini merupakan inti dari AHP, karena ia akan berpengaruh terhadap prioritas elemen- elemen. Dalam penyusunan skala kepentingan ini, digunakan acuan seperti pada tabel 1 berikut:

Tabel 1 Skala prioritas dalam AHP

\begin{tabular}{|c|l|}
\hline $\begin{array}{c}\text { Nilai } \\
\text { Numerik }\end{array}$ & \multicolumn{1}{c|}{ TingkatKepentingan (Preference) } \\
\hline 1 & Sama pentingnya (Equal Importance) \\
\hline 2 & Sama hingga Sedikit Lebih penting \\
\hline 3 & Sedikit Lebih penting (Slightlymore Importance) \\
\hline 4 & Sedikit Lebih hingga Jelas lebih penting \\
\hline 5 & Jelas lebih penting (Materiallymore Importance) \\
\hline 6 & Jelas hingga Sangat jelas lebih penting \\
\hline 7 & Sangat jelas lebih penting (Significantlymore Importance) \\
\hline 8 & Sangat jelas hingga Mutlak lebih penting \\
\hline 9 & Mutlak lebih penting (Absolutelymore Importance) \\
\hline
\end{tabular}

3. Synthesis of Priority

Dari setiap pairwise comparison kemudian dicari eigenvector-nya untuk mendapatkan local priority. Karena matriks pairwise comparison terdapat pada setiap tingkat, maka untuk mendapatkan global priority harus dilakukan sintesa diantara local priority. Prosedur melakukan sintesis berbeda menurut bentuk hirarki. Pengurutan elemen-elemen menurut kepentingan relatif melalui prosedur sintesa dinamakan priority setting.

4. Logical Consistency 
Konsistensi memiliki dua makna. Pertama adalah bahwa objek-objek yang serupa dapat dikelompokkan sesuai dengan keseragaman. Kedua adalah menyangkut tingkat hubungan antara objek-objek yang didasarkan pada kriteria tertentu.

\section{Perhitungan Analitycal Hierarcy Process}

Elemen-Elemen pada setiap baris dari matriks persegi merupakan hasil perbandingan berpasangan. Setiap matriks pairwise comparison dicari eigen vektornya untuk mendapat local priority. Skala perbandingan berpasangan didasarkan pada nilai-nilai fundamental Analitycal Hierarcy Process dengan pembobotan dari i untuk sama penting, sampai dengan 9 untuk sama penting sekali. Penyimpanan dari konsistensi dinyatakan dalam indeks konsistensi yang didapat dari rumus:

Menghitung nilai maksimum eigen / maximum Eigen Value ( $\lambda$ max), sebagai berikut: $\lambda$ max $=$ jumlah elemen pada matriksY

Menghitung nilai Consistency Index (CI)

Menghitung nilai Consistency Ratio (CR)

$$
\begin{aligned}
\mathrm{N}-1 & \\
& \\
& \frac{\mathrm{CR}=\mathrm{max}-\mathrm{N}}{\text { Random Index (tabel) }} \ldots \ldots . . .(2)
\end{aligned}
$$

Keterangan :

$$
\begin{array}{ll}
\lambda \max & =(\text { Maximum Eigen Value }) \\
\mathrm{N} & =(\text { Ukuran matriks }) \\
\mathrm{CR} & =(\text { Consisntency Ratio }) \\
\mathrm{CI} & =(\text { Consistency Index }) \\
\mathrm{Y} & =(\text { Jumlah elemen pada matriks })
\end{array}
$$

\section{Tahapan pengambilan keputusan dalam metode AHP}

1. Mendefinisikan masalah dan menentukan solusi yang diinginkan.

2. Membuat struktur hirarki yang diawali dengan tujuan umum, dilanjutkan dengan kriteria yang ingin di rangking.

3. Membentuk matriks perbandingan berpasangan. Perbandingan dilakukan berdasarkan pilihan atau judgement dari pembuat keputusan dengan menilai tingkat-tingkat kepentingan suatu elemen dibandingkan elemen lainnya.

4. Menormalkan data yaitu dengan membagi nilai dari setiap elemen di dalam matriks yang berpasangan dengan nilai total dari setiap kolom.

5. Menghitung nilai eigen vector dan menguji konsistensinya, jika tidak konsisten maka pengambilan data (preferensi) perlu diulangi. Nilai eigen vector yang dimaksud adalah nilai eigen vector maksimum yang diperoleh dengan menggunakan matlab maupun dengan manual.

6. Mengulangi langkah, 3, 4, dan 5 untuk seluruh tingkat hirarki.

7. Menghitung eigen vector dari setiap matriks perbandingan berpasangan. Nilai eigen vector merupakan bobot setiap elemen. Langkah ini untuk mensintetis pilihan dalam penentuan prioritas elemen pada tingkat hirarki terendah sampai pencapaian tujuan.

8. Menguji konsistensi hirarki. Jika tidak memenuhi dengan $\mathrm{CR}<0,100$ maka penilaian harus diulangi kembali. 


\section{PEMBAHASAN/PEMECAHAN MASALAH}

Perancangan sistem ini bertujuan untuk menghasilkan suatu sistem pendukung keputusan (Decision Support System) yang dapat membantu dewan penguji dalam menentukan kelulusan mahasiswa pada program studi ground handling airlines sesuai dengan kriteria dan bobot penilian yang telah ditentukan pada program studi tersebut.

Panitia mahasiswa baru dan dewan pengujian dalam tes wawancara memiliki hak akses dalam menggunakan sistem. Panitia memiliki level yang lebih tinggi daripada dewan penguji yang hanya berhak menggunakan sistem ini sebagai bahan penilaian kepada calon mahasiswa yang telah terdaftar oleh panitia pendaftar.

Dewan penguji terdiri dari 4 orang, masing masing dewan penguji akan memberikan point nilai berdasarkan sub-penilaian yang ada kepada calon mahasiswa yang telah dilakukan pengujiannya, hasil penilaian yang telah diberikan oleh 4 orang dewan penguji ke dalam sistem dapat menghasilkan suatu hasil akhir sesuai bobot penilaian yang akan dijadikan sebagai penentu sebuah kelulusan pada program studi ground handling airlines sesuai ketentuan yang ada.

Berikut ini adalah proses utama dalam sistem pendukung keputusan penilaian kinerja kader dengan metode AHP :

a) Proses Pengolahan User

Memiliki 2 Hak akses yang berbeda dalam penggunaan sistemnya serta cara pemakaian yang berbeda yaitu Panitia dan Dewan Penguji.

b) Proses Autentifikasi User

Tahapan ini adalah proses login yaitu tahap pembuktian atau validasi data user ketika memasuki lingkungan sistem yang telah dibuat yang membedakan suatu hak akses antara panitia dan dewan penguji.

c) Proses Pengolahan Nilai atau Bobot Kriteria dengan Metode AHP

Proses pembobotan atau pemberian nilai dan juga pengukuran penentu kelulusan dalam prodi ground handling airlines. Dalam proses ini ada beberapa tahapan penilaian atau pemberian bobot yaitu :

1. Pengolahan Kriteria

Pada tahapan ini panitia pendaftaran akan memasukan data pendaftar singkat yang meminta data berat dan tinggi badan, serta nilai rata-rata ujian nasional dari calon mahasiswa. Berguna untuk menjadi kriteria penentuan kelulusan mahasiswa pada prodi tersebut yang akan menghasilkan bobot penilian.

\section{Perbandingan Kriteria}

Pada tahapan ini yang berperan sebagai dewan penguji akan membandingkan masingmasing kriteria satu dengan yang lainnya sehingga dapat menghasilkan nilai perbandingan yang dapat dijadikan sebagai skala prioritas dalam penentuan kelulusan.

3. Pengolah Sub Kriteria

Pada tahapan ini sistemakan melakukan perhitungan yang diperlukan dari hasil penilaian dewan penguji dengan melakukan perkalian antara bobot kriteria dengan 
nilai/option subkriteria pada ujian yang dilalui oleh calon mahasiswa.Tahapan ini dalam metode AHP biasa disebut synthesizing.

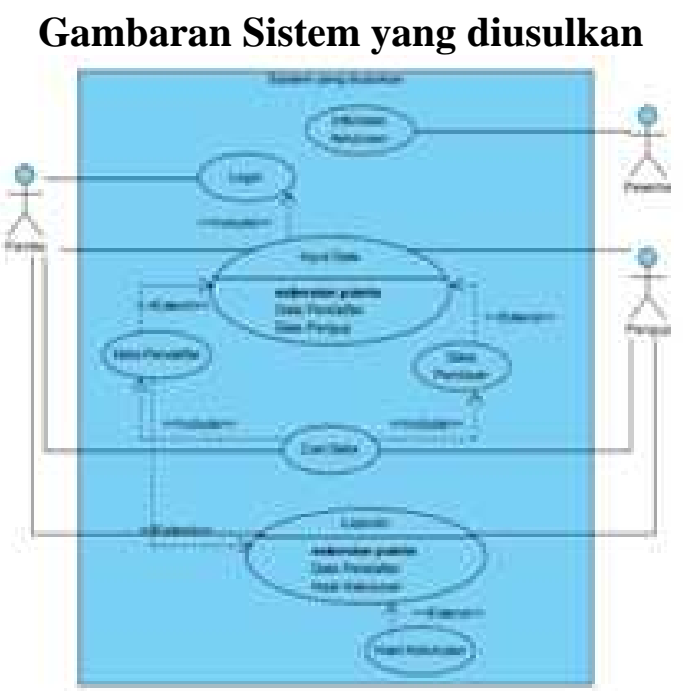

\section{Gambar 3. Use Case Diagram Usulan}

Berdasarkan gambar 3 Use Case Diagram Usualan di atas terdapat :

1. Satu (1) system yang mencakup seluruh kegiatan yang sedang berjalan

2. tiga (3) actor yang melakukan kegiatan, yaitu Panitia, Dewan Penguji, Peserta

3. delapan (8) use case yang biasa dilakukan oleh actor

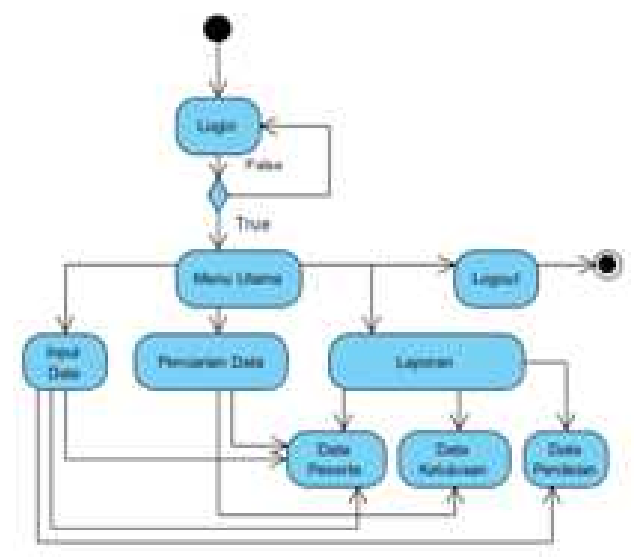

Gambar 4. Model Activity Diagram Usulan

Dari gambar 4 di atas, terdapat:

1. Satu (1) Initial Node : Titil Awal Mulai

2. Delapan (9) Action : Login, Menu Utama, Melakukan Input data, Pencarian Data, Laporan dan Logout.

3. 1 decision node, proses keputusan.

4. 1 final node, objek yang diakhiri 
Model Sequence Diagram yang Diusulkan

a. Sequence Diagram Login

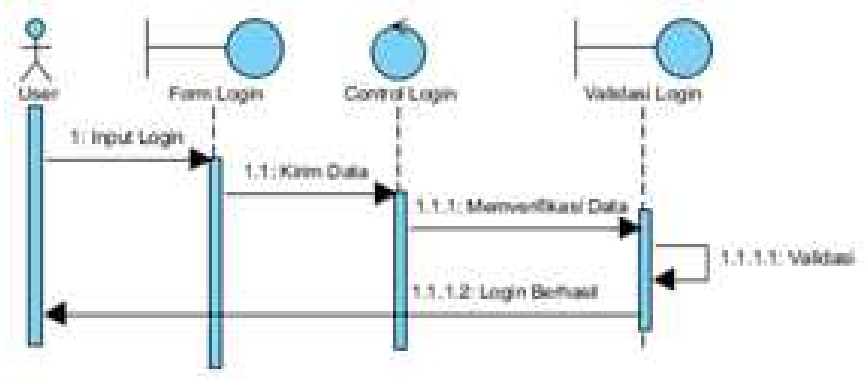

\section{Gambar 5. Model Sequence Diagram Login}

Berdasarkan gambar 5 di atas, terdapat:

1. Satu (1) Actor melakukan kegiatan yaitu panitia dan dewan penguji

2. Lima (5) Message yang saling terhubung.

3. 3 Lifeline yang saling berinteraksi.

b. Sequence Diagram Input Data Pendaftar

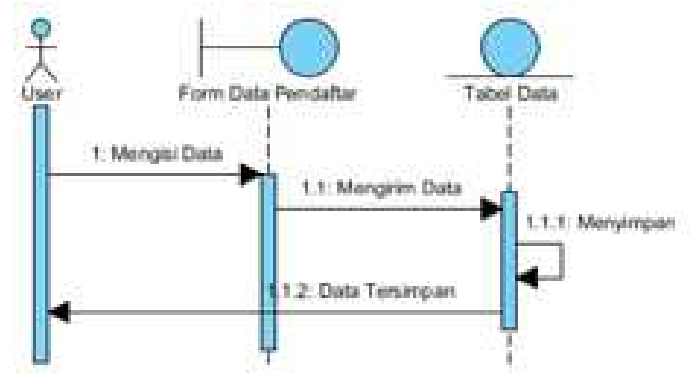

\section{Gambar 6. Sequence Diagram Input Pendaftar}

Berdasarkan Sequence Diagram Input pendaftar pada gambar 6 di atas, terdapat:

1. Satu (1) Actor melakukan kegiatan yaitu Panitia

2. Empat (4) Message yang terhubung

3. Dua Life line saling berinteraksi

c. Sequence Diagram Input Data Penilaian

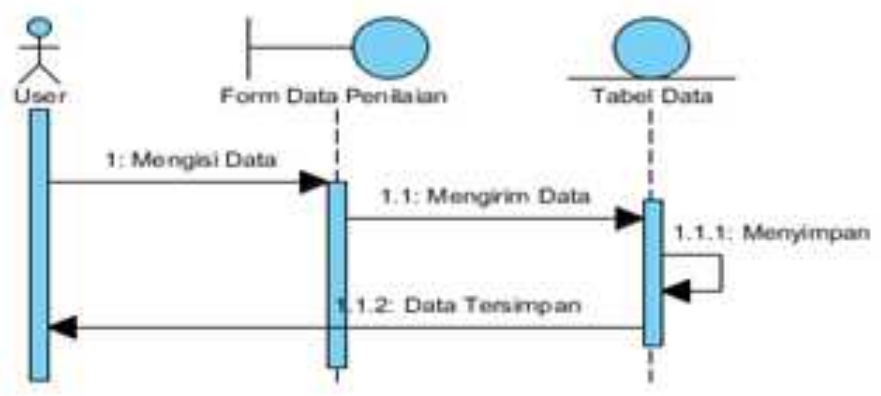

Gambar 7. Sequence Diagram Input Data Penilai

Berdasarkan Sequence Diagram Input Data Penilai pada gambar 7 di atas, terdapat: 
1. Satu (1) Actor melakukan kegiatan yaitu Dewan Penguji

2. Empat (4) Message yang terhubung

3. Dua Lifeline saling berinteraksi

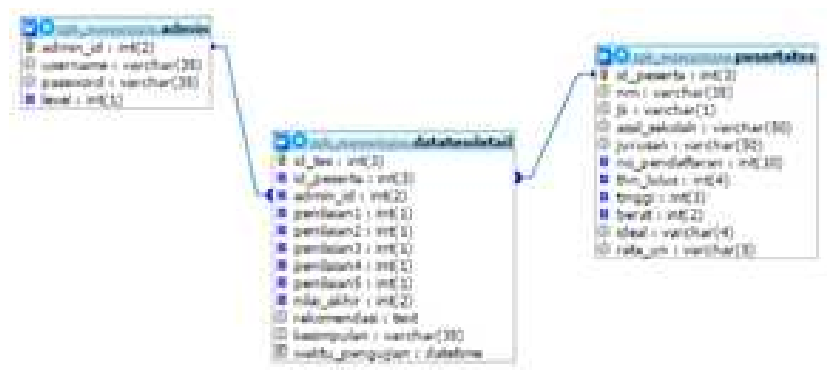

Gambar 8. Class Diagram Usulan

Pada gambar 8 di atas, class diagram yang digunakan dalam pemodelan suatu sistem berbasis Object Oriented (OO) yang menggambarkan secara keseluruhan struktur database secara detail dengan menyertakan properties serta attributnya.

\section{IMPLEMENTASI}

1. Tampilan Halaman Home Tanpa Hak Akses /Umum

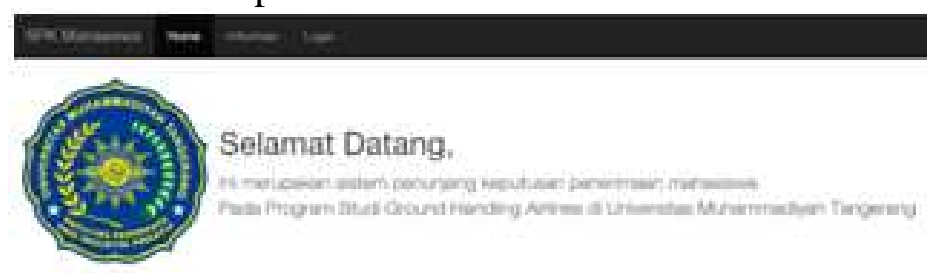

\section{Gambar 9. Tampilan Halaman Home Tanpa Hak Akses/Umum}

Pada menu ini (Gambar 9), user hanya bisa sebagai viewer yang tidak memiliki hak akses apapun.User hanya bisa melihat hasil akhir dari kelulusan.User tanpa hak akses hanya bisa melihat menu navigasi Home, Informasi.

2. Tampilan Halaman Login

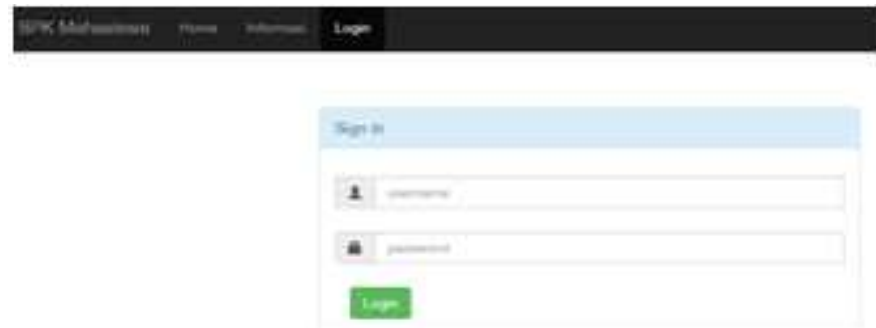

\section{Gambar 10. Tampilan Halaman Login}

Pada menu ini (Gambar 10), terdapat Authentification process dimana terjadi validasi terhadap username dan password yang dimasukkan terhadap username dan password yang ada pada database. Yang akan memisahkan hak akses panitia dan dewan penguji. 
3. Tampilan Halaman Input Data Peserta

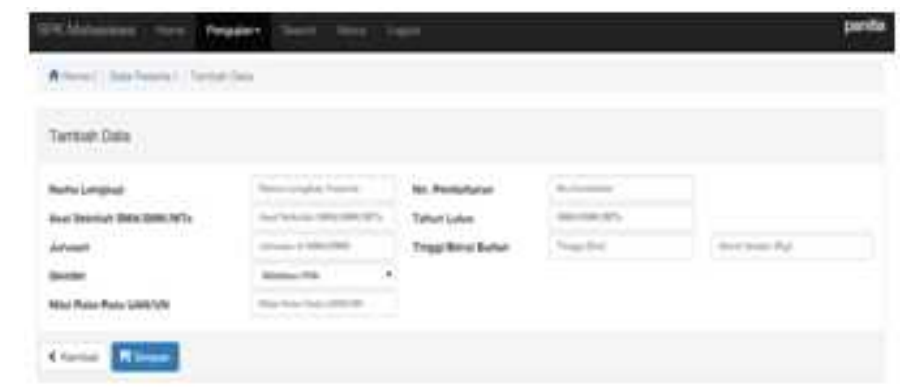

Gambar 11. Tampilan Halaman Input Data Peserta

Pada menu tambah data ini (gambar 11), hak akses dikendalikan penuh oleh panitia. Dalam sistem ini akan menghasilkan bobot penilaian akhir dari tinggi berat badan ideal dari kriteria tinggi berat badan laki-laki atau perempuan dan mendapatkan hasil bobot penilaian akhir dari data yang di masukan pada nilai rata-rata ujian nasional (UN).

a) Pembahasan Algoritma Menu

Di dalam menu ini terdapat field No Pendaftaran,yang digunakan sebagai primary key atau pembeda yang memberikan ciri khas pada masing - masing data yang juga akan memberikan kemudahan dalam melakukan pencarian data.

Field Gender merupakan field yang akan diisi sesuai dengan calon peserta.Tahapan ini akan memecah berhubungan dengan kriteria pada field tinggi dan berat badan yang akan menghasilkan bobot penilaian berat badan ideal dengan capaian maksimal $10 \%$.

Perhitungan Berat Badan Ideal

Laki-Laki

(tinggi badan-100)-(10\%*(tinggi badan-100)

Perempuan

$$
\text { (tinggi badan-100)-(15\%*(tinggi badan-100) }
$$

4. Tampilan Halaman Pengujian

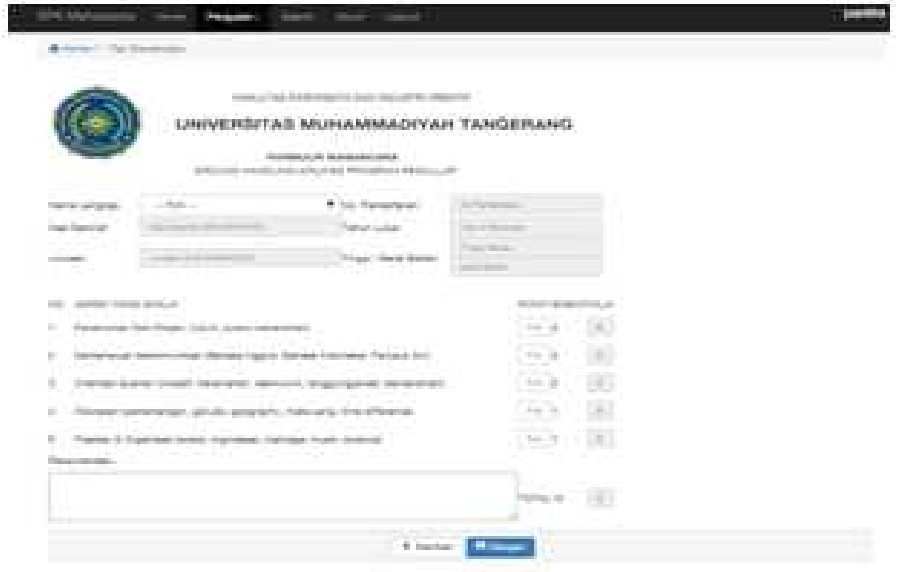

Gambar 12. Tampilan Halaman Pengujian 
Pada menu pengujian tes wawancara ini (gambar 12), hak akses dikendalikan penuh oleh dewan penguji, dimana dewan penguji terdiri dari 4 oang. Dalam sistem ini akan menghasilkan bobot penilaian akhir dari hasil penilaian yang diberikan oleh dewan penguji dalam field point. Dimana field point akan dikalikan dengan bobot yang sudah ditentukan setiap kriteria tes wawancaranya dan menghasilkan total setiap dewan penguji. Total akhir nilai yang didapatkan oleh 4 dewan penguji akan di gabungkan sehingga mendapatkan nilai maksimal $80 \%$ dimana setiap dewan penguji bisa mencapai penilian maksimal $20 \%$.

Keterangan point yang diberikan (gambar 13 dan 14)

Range Point Peniilaian $1-5$

Keterangan :

$$
\begin{aligned}
& 1=\text { Tidak Memuaskan } \\
& 2=\text { Kurang Memuaskan } \\
& 3=\text { Cukup Memuaskan } \\
& 4=\text { Memuaskan } \\
& 5=\text { Sangat Memuaskan }
\end{aligned}
$$

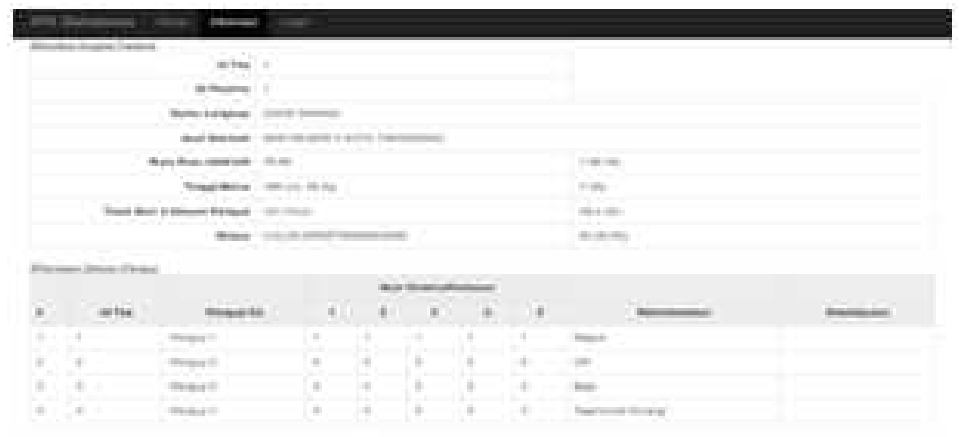

Gambar 13. Keterangan Point yang Diberikan

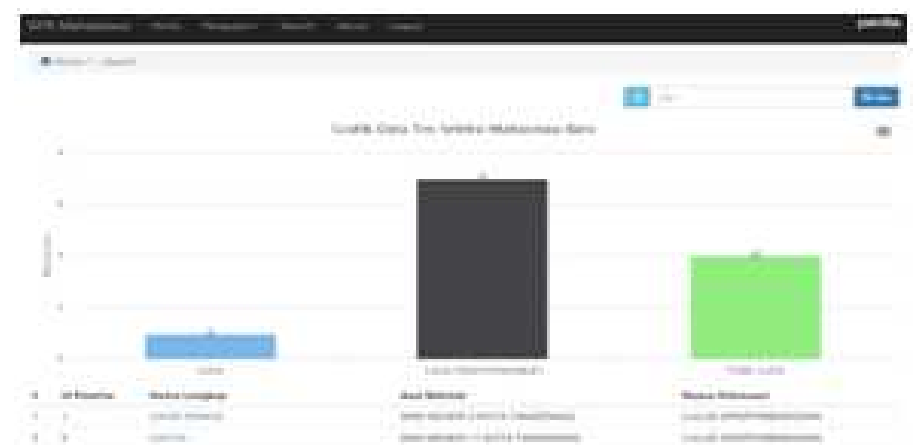

Gambar 14. Grafik Data Tes Mahasiswa Baru

Sistem ini akan memberikan suatu keputusan akhir dengan 3 Kriteria:

Tabel 2 Kriteria Keputusan Akhir

\begin{tabular}{|c|c|}
\hline Status & $\%$ Persentase \\
\hline Lulus & $>70 \%$ \\
\hline
\end{tabular}




\begin{tabular}{|c|c|}
\hline Lulus Dipertimbangakan & $>55 \%$ \\
\hline Tidak Lulus & $<=55 \%$ \\
\hline
\end{tabular}

Pada tabel 2, Setiap status akan memiliki track record dalam membantu dewan penguji ketika dalam masa pendidikan kelak calon mahasiswa prodi ground handling, agar bisa melatih dan mendidik catatan perbaikan ketika awal di pengujian ketika menjadi calon mahasiswa dan siap menjadi sebuah lulusan terbaik di industri penerbangan ketika selesai masa pelatihan dan pendidikan ground handling airlines.

\section{KESIMPULAN}

Berikut kesimpulan perihal rumusan masalah mengenai Penetapan Analytical Hierarchy Process (AHP) Sebagai Model Penunjang Keputusan Penerimaan Mahasiswa Program Studi Ground Handling Airlines Pada Universitas Muhammadiyah Tangerang adalah sebagai berikut:

1. Sistem yang berjalan pada saat ini pada proses penerimaan mahasiswa baru yaitu dilakukan dengan cara manual, basis data tanpa terintegrasi oleh sistem komputer, yang berakibat adanya data ganda dan memerlukan waktu yang tidak sedikit dalam up to date datanya. dengan demikian dibuatkan suatu sistem penunjang keputusan dapat membantu dalam kecepatan penyampaian up to date datanya.

2. Kendala yang dihadapi dalam proses penerimaan mahasiswa pada program studi ground handling adalah perhitungan penilaian akhir dari setiap dewan penguji harus dihitung kembali total keseluruhan nilainya, kemudian informasi kelulusannya masih memerlukan waktu berikutnya tidak secara langsung, serta dalam perekapan datanya masih manual melihat dari setiap form baik itu penilaiannya maupun hasil dari tes yang telah dilakukannya sehingga pengolahannya data belum optimal dikarenakan belum terkomputerisasi.

3. Sistem ini dirancang menggunakan metode Analytical Hierarchy Process (AHP) dengan kriteria yang ditentukan dalam pengambilan keputusan sehingga diharapkan mampu memberikan informasi secara cepat tanpa memerlukan waktu yang tidak sedikit dan membantu dalam keakuratan dalam penerimaan mahasiswa baru sesuai dengan criteria yang diharapkan oleh program studi Ground Handling Airlines.

\section{DAFTAR PUSTAKA}

[1] Bartalanfy, Von, Ludwig, Konsep Sistem Informasi, Diakses pada tanggal 18 April 2007.

[2] Mustakin, Jogiyanto Hartono, Analisis dan Desain : Sistem Informasi Pendekatan Terstruktur Teori dan Praktek Aplikasi Bisnis, Edisi III, Andi Offset, Yogyakarta, hal 64.

[3] Al Fata, Sistem Informasi Manajemen, Bandung hal 9, 2007

[4] Vercellis, Carlo. (2010). Business intelligence : Data mining and optimization for decision making. Chichester: John Wiley \& Sons.

[5] Nofriansyah, Dicky.2014.Konsep Data Mining vs Sistem Pendukung Keputusan/ oleh Dicky Nofriansyah-Ed.1,Cet.1-Yogyakarta: Deepublish.

[6] Magdalena, Hilyah. 2012. Sistem Pendukung Keputusan Untuk Menentukan Mahasiswa Lulusan Terbaik di Perguruan Tinggi (Studi kasus STMIK Atma Luhur Pangkalpinang).Seminar Nasional Teknologi Informasi dan Komunikasi 2012 (SENTIKA 2012). Yogyakarta, 10 Maret 2012. 
[7] Saaty, T. Lorie.1993.Pengambilan Keputusan Bagi Para Pemimpin, Proses Hirarki Analitik untuk Pengambilan Keputusan dalam Situasi yang Kompleks. Seri Manajemen No. 134.Jakarta : PT. pustaka Binaman pressindo.

[8] Mulyono, Sri.2007.Riset Operasi. Edisi Revisi (2007). Lembaga Penerbit Fakultas Ekonomi Universitas Indonesia, Jakarta 